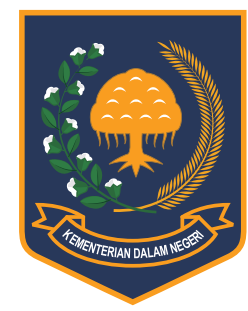

Jurnal Bina Praja 8 (2) (2016): 187-197

Jurnal Bina Praja

e-ISSN: 2503-3360 | p-ISSN: 2085-4323

Accreditation Number

735/AU2/P2MI-LIPI/04/2016

http://jurnal.kemendagri.go.id/index.php/jbp/index

\title{
Public Policy in Managing Modern Stores FOR COMMUNITY DEVELOPMENT
}

\author{
Suroso ${ }^{1, *}$ \\ ${ }^{1}$ Research and Development Office, Pati Regency \\ Jl. Panglima Sudirman, Pati - 59113
}

Received: 22 June 2016; Accepted: 7 October 2016; Published online: 30 November 2016

DOI: $10.21787 / \mathrm{jbp} .08 .2016 .187-197$

\begin{abstract}
Modern stores have grown rapidly in Pati Regency but some of them are out of control, such as too near traditional markets. The objective of the research is to analyse the existence of modern stores, the distribution of them, the local government regulation of them, and to analyse advantages and disadvantages of them for community development. This research uses descriptive quantitative approach. Data collecting is conducted by observation, interview, and field events. This research uses descriptive analysis. There are five main findings in the research. Firstly, modern stores in the study area have grown rapidly. Secondly, the distribution of modern stores is not well managed, in which 19 out of 53 modern stores $(35,84 \%)$ are established in the sites near traditional markets. Thirdly, the existence of modern stores is not well controlled because 9 out of 53 modern stores are in problems with their permits. Fourthly, there are 20 modern stores which have roles in community development by providing retail space for informal traders. Fifthly, the local government policy concerning minimarket is not well formulated being not governed the distance between modern store to the pre-existing traditional markets and being to conduct a moratorium of permit serving for the establishment of modern stores, which does not refer to national law. Therefore, the existing local policy in managing modern stores should be reviewed to support community development.
\end{abstract}

Keywords: community development, modern store, public policy.

\section{INTRODUCTION}

Recently, modern stores, including mini markets and supermarkets, have grown rapidly in Pati Regency. It is an indication that the local government tends to be out of control in managing the growth of modern stores. Some modern stores are established near traditional markets. Two minimarkets in Batangan (eastern part of Pati Regency) for instance are established in the surrounding traditional markets, the distance is about 20 meters. Even some modern stores have no permits or use the permits falsely, not as stated in the legal document.

The establishment of modern stores, which are near traditional markets, will be vulnerable to influence the existing of traditional markets. Most studies show that modern stores which are established near traditional markets have potential impacts to the existence of traditional markets.
A study, which was conducted by Pusoro (2007), stated that the existence of supermarket influenced the decrease performance of traditional markets. Relevant to the study, Fadhilah (2011) stated that there are many impacts from the establishment of modern markets to the surrounding traditional markets. In general, the impact is that the income for retailers in the traditional market decreases. Among 71 retailers of daily needs in the traditional market stated that 37 retailers $(52.11 \%)$ got decreased their sale of rice, 52 retailers $(73.23 \%)$ got decreased their sale of eggs, 44 retailers (61.97\%) got decreased their sale of white sugar, 40 retailers $(56.33 \%)$ got decreased their sale of cooking oil, 53 retailers $(74.47 \%)$ got decreased their sale of noodle, 65 retailers $(91.54 \%)$ got decreased their sale of milk, 23 retailers (32.39\%) got decreased their sale of wheat flour and 39 retailers (54.92\%) got decreased their sale of soap. The decreasing sales of the daily needs made the retailers' income

\footnotetext{
* Corresponding Author

Phone : +6285201027 201

Email : suroso_peneliti@yahoo.co.id
} 
decreased.

Going in line with the previous description, Aryani (2011) concluded that there are different incomes for retailers in traditional markets in preexistence and post-existence of modern markets. Decreasing income for retailers in traditional markets will influence their profit. Sihotang (2014) stated that Modern Markets have a negative impact on sales and profit of traditional markets. In line with the study by Widiandra (2013), which stated that there is an influence of profit for traditional markets which is caused by modern markets. The impact of modern stores to traditional markets or traditional stores depends on the distance between them. Iffah et al.. (2011) stated that one of minimarkets in the region of Blimbing District has affected the four traditional stores surrounding them, with an average of $57.29 \%$ friction. When the traditional retail is far from minimarket, the effect becomes smaller and when the traditional retail is near from minimarket, the effect is bigger.

Most studies show that modern stores which are established near to traditional markets have potential impacts to the existence of traditional markets. However, the effect of modern stores becomes smaller when the distance is far away. Even though modern stores have negative impacts on one side, they have potential good effects on development in another side. One of the good effects is the enlargement of employment. It is useful for community development. It is undeniable that employment is needed for community development because recently employment growth is slowing down. Since the outbreak of the crisis, employment growth has slowed to $1.2 \%$ per annum between 2007 and 2014. On current trends, unemployment will continue to rise as the labour force expands. Going forward, job creation is expected to remain at this lower growth rate over the medium term, causing a widening of the global jobs gap to around 82 million jobs in 2019. If new labour market entrance is taken into account, 280 million jobs will need to be created over the coming five years to close the crisis-related global jobs gap and to absorb the increase in the labour force (ILO, 2015).

Modern stores which are established near to traditional markets have potential impacts to the existing of traditional markets but they are also useful to enlarge employment. Responding to the facts, it is needed a public policy to eliminate the negative impacts of modern stores to traditional markets without stopping them to enlarge employment in order to reduce unemployment.

The term "Policy" primarily refers to guidelines and interventions for the changing, maintenance or creation of living conditions that are conducive to human welfare (Hernandez et al.., 2011). Relevant to it, Commonwealth Secretariat (2007) stated that "policy' means a set of guidelines or decisions that determine and underline the way individuals or groups of people think and behave in a certain social, cultural, economic and political environment. The policy which is made by the government is called "public policy". According to Nugroho (2006) "Public policy" is everything which is done by governments respecting to why they do it and what make the impacts for better living. "Public policy" may refer economic policy and social policy (Hernandez et al., 2011). There are different approaches in management, especially in today's turbulent ongoing days. Because environment changes a lot so policies and policy making strategies always changes and becomes more complicated. Now policy-based management is one of these strategies. Policy-based management is an administrative approach that is used to simplify the management of a given endeavour by establishing policies to deal with situations that are likely to occur. Policies are operating rules that can be referred to as a way to maintain order, security, consistency, or otherwise forth a goal or mission.

A public policy is usually formulated using certain steps. Anderson in Subarsono (2005) stated that public policy consists of the following steps: (1) agenda setting, selecting public issues which is necessary to overcome; (2) policy formulation, identifying policies which are possibly used to handle the issues; (3) policy adoption, selecting choices of the policy by supporting administrator and legislative. The policy adoption is conducted after the process of recommendation is over; (4) policy implementation, the phase in which the follow-up of policy adoption is conducted by related institutions with supporting available resources; and (5) policy assessment, the phase in which evaluation is conducted to determine the existence of effectiveness and efficiency of the policy.

A public policy always has different contents but mainly there are some similarities among them. Below, we bring the common ones. Firstly, a purpose statement, outlining why the organization is issuing the policy, and what its desired effect or outcome of the policy should be. Secondly, an applicability and scope statement, describing who the policy affects and which actions are impacted by the policy. The applicability and scope may expressly exclude certain people, organizations, or actions from the policy requirements. Applicability and scope are used to focus the policy on only the desired targets, and avoid unintended consequences where possible. Thirdly, an effective date which indicates when the policy comes into force. Retroactive policies are rare, but can be found. Fourthly, a responsibilities section, indicating which parties and organizations are responsible for carrying out individual policy statements. Many policies may require the 
establishment of some ongoing function or action. For example, a purchasing policy might specify that a purchasing office is created to process purchase requests and that this office would be responsible for ongoing actions. Responsibilities often include identification of any relevant oversight and/or governance structures. Fifthly, policy statements indicating the specific regulations, requirements, or modifications to organizational behaviour that the policy is creating. Policy statements are extremely diverse depending on the organization and intent and may take almost any form (Irani \& Noruzi, 2011).

In the context of the public policy in managing modern stores in Indonesia, it is mandated in the Regulation of the President No 112 of 2007. Therefore, the local government has the responsibility to manage the existence of modern stores properly so their existence does not influence the existing of traditional markets. The term "Modern Store" means an independent self-service store that retails a large variety of goods through Minimarkets, Supermarkets, Department Stores, Hypermarkets or grocers that constitute Grocery Stores.

The Classification of modern stores can be identified by their size of retail space. Suitable for the Regulation of the President No 112 of 2007, retail space of modern stores are as follows: (a) Minimarkets, less than $400 \mathrm{~m}^{2}$ (four hundred meters square); (b) Supermarkets, $400 \mathrm{~m}^{2}$ (four hundred meters square) to $5,000 \mathrm{~m}^{2}$ (five thousand meters square); (c) Hypermarkets, above 5,000 $\mathrm{m}^{2}$ (five thousand meters square); (d) Department Stores, above $400 \mathrm{~m}^{2}$ (four hundred meters square); (e) Grocery Stores, above 5,000 $\mathrm{m}^{2}$ (five thousand meters square). The establishment of Modern Stores must: (a) Extrapolate the social-economic condition of the community, the presence of Traditional Markets, Small Enterprises, and Medium Enterprises exist in the area concerned; (b) Observe the distance between Hypermarkets and preexisting Traditional Markets; (c) Provide parking space for at least 1 (one) four-wheel motor vehicle per $60 \mathrm{~m}^{2}$ (sixty meters square) of retail space of Shopping Centres and/or Modern Stores; and (d) To provide facilities that assure that Shopping Centres and Modern Stores are clean, sanitary (hygienic), safe, orderly, and served with convenient public space.

Based on the regulation above, the local government is mandated to manage modern stores properly so their existence does not influence the existence of traditional markets. Recently, there is Regulation of the Trade Minister No 68/M-Dag/ PER/10/2012 regarding the Franchise for Modern Store. This regulation governs the limit of the company owned outlet maximally 150 outlets and if exceeding such maximal limitation then it is mandatory to franchise its business. The Regulation limits the number of company-owned franchise outlets to 150 . If a franchisor already has 150 stores and plans to increase the number, then 40 $\%$ of the additional outlets should be franchised. For example, if a franchise owner with 150 outlets plans an additional 200 , then $40 \%$ of the 200 must be franchised.

It implies that both modern stores and traditional markets are needed to support community development so the local government should manage them wisely. The term "community" is a diverse group of people who live in a commonly understood location or place. The place may be a neighbourhood, a town/city, or a county and community development is a process that helps a community to sustain itself socially, economically, and environmentally (Majee, 2011).

Based on the previous description, the public policy in managing modern stores should guarantee the sustainability of traditional markets. The objectives of the research are (a) to analyse the existence of modern stores; (b) to analyse the distribution of modern stores; and (c) to analyse the local government regulation of them; (d) advantage and disadvantage of modern stores for community development in the study area. It is undeniable that modern stores are useful to support city development and community development. However, the establishment of modern stores which is out of control may influence the existence of traditional markets. In other words, modern stores are needed to support community development as long as they do not influence the performance of traditional markets so the growth of them should be managed properly. These are the reasons why this study is conducted. The results of this study are useful to support a policy making in managing modern stores and traditional markets simultaneously. The establishment of modern stores should not influence the existence of traditional markets.

\section{MeTHOD}

This research is conducted in Pati Regency. It is situated in the eastern part of Central Java Province. It has 21 districts and 406 village/subdistricts. The research uses descriptive quantitative approach. There are four variables in the research: (a) the existence of modern stores; (b) distribution of modern stores; (c) advantage and disadvantage of them for community development; and (d) local government policy of modern stores in the study area. The data consists of primary data and secondary data. The primary data is obtained from field observation (distances between of modern stores to the traditional markets) and interview 
Table 1.

Existing of Modern Stores in Pati Regency

\begin{tabular}{|c|c|c|c|}
\hline \multirow{2}{*}{ Year } & \multicolumn{2}{|c|}{ Establishments of Modern Stores } & \multirow{2}{*}{ Additional Information } \\
\hline & Minimarket & Supermarket & \\
\hline 2005 & 1 & 0 & First establishment permit of minimarket** \\
\hline 2006 & 1 & 0 & \\
\hline 2007 & 2 & 0 & \\
\hline 2008 & 16 & 1 & 1 supermarket and 1 minimarket in permit problems* \\
\hline 2009 & 6 & 0 & \\
\hline 2010 & 8 & 0 & 1 minimarket in problems (permit deviation)* \\
\hline 2011 & 8 & 0 & 1 minimarket in problems (permit deviation)* \\
\hline 2012 & 6 & 1 & 2 minimarket in problems, no permits* \\
\hline 2013 & 1 & 0 & 1 minimarket in problem, no permit* \\
\hline 2014 & 1 & 0 & 1 minimarket in problem, no permit* \\
\hline 2015 & 1 & 0 & 1 minimarket in problem (permit deviation)* \\
\hline Total & 51 & 2 & 9 modern stores in permits problems \\
\hline
\end{tabular}

Source: Kayandu and survey, 2015

* permits (secondary data) are compared to the facts in the fields

** permit (Kayandu, 2015)

to the resource persons at the office of integrated service (Kayandu), retailers in the traditional markets and employees of modern stores and civil society. The secondary data is obtained from related institutions including the data from the office of integrated service (Kayandu), the industry and trading agency (Disperindag) and the board of empowerment for villages (Bappermades). The research uses descriptive analysis.

\section{RESULT AND DISCUSSION}

\section{A. The Existence of Modern Stores in Pati Regency}

The developmentsandestablishment of modern stores such as mini markets and supermarkets are expected to support community development. Modern stores need employees so the existence of modern stores may reduce unemployment problem. On the other hand, the establishment of modern stores which are improperly controlled may have negative impacts to the existence of traditional markets. Therefore, the role of the local government is very important to manage the development of modern stores.

Recently modern stores, including mini market and supermarket, grow rapidly in Pati Regency. The first permit for the establishment of modern stores is issued in 2005. In 2015, Pati Regency has 53 modern stores including 51 minimarkets and 2 supermarkets. Averagely, there are 5 new modern stores establishment annually. The existence of modern stores in Pati Regency are shown in the Table 1.

Dealing with the stores, there are 9 of 53 modern stores (16.98\%) in problem with their permits. Some have no permit and others have permits but use the permits improperly as stated (deviate usage of permits).

Firstly, there is one of two supermarkets that has complex problems including (a) the status of permit remains minimarket, the physical building and activities are included in the category of supermarket but its permit is still minimarket. Its retail space is about $1,000 \mathrm{~m}^{2}$. Suitable for the Regulation of the President No 112 of 2007, retail space of minimarket is less than $400 \mathrm{~m}^{2}$ (four hundred meters square) and retail space of supermarket is $400 \mathrm{~m}^{2}$ (four hundred meters square) to $5,000 \mathrm{~m}^{2}$ (five thousand meters square). (b) the distance is too near to the existing traditional market. One supermarket is near to Rogowongso Market (traditional market). The distance of the supermarket to Rogowongso Market is about 200 $\mathrm{m}^{2}$ (two thousand meters square). The impact is less and less customers (buyers) in the traditional markets. (c) the parking area is not feasible. 
According to Regulation of the President No 112 of 2007, the establishment of shopping centres and modern stores must provide parking space for at least 1 (one) four-wheel motor vehicle per $60 \mathrm{~m}^{2}$ (sixty meters square) of retail space of shopping centres and/or modern stores. Respecting to provide parking area, one supermarket in Pati Regency does not have feasible parking area especially for a fourwheel vehicle. As result, the road in front of the supermarket is overcrowded because of parking cars on the sides of the road.

Secondly, there are some problems dealing with the establishment of minimarkets. Among 8 of 51 minimarkets (15.69\%) have problems with their permits. Four of them use the permits improperly (misusing permits). The actual stores are not suitable to the permits. It shows that there is a weakness in the control of managing modern stores. The others ( 4 minimarkets) have no permits for the establishment of modern stores. These are the impacts of the regulation (Regent Regulation No 60 of 2012) which conducts moratorium for serving permit establishment of minimarkets. Briefly, there are some weaknesses in managing modern stores in Pati Regency.

Table 2.

Distribution of Modern Stores in Pati Regency

\section{B. The Distribution of Modern Stores}

In the context of community development, modern stores and traditional markets are both needed to increase the development. Unfortunately, some modern stores are established too near to the traditional markets. The distance between modern stores and existing traditional markets which are too near indicates that local policy is improperly conducted to manage the distribution of modern stores. Three minimarkets in Batangan District for instance (eastern part of Pati Regency) are all in problems. Their distance is too near traditional markets, less than 50 meters. The establishments of modern stores, which are near the existing traditional markets in Pati Regency are shown in the Table 2.

Pati Regency has 53 modern stores including 2 supermarkets and 51 mini markets. There are 19 of 53 modern stores (35.84\%) which are established too near traditional markets. The distances of the modern stores to the existing traditional markets are less than 500 meters. These findings refer to improperly conducting policy of the local government in controlling the distribution of the modern stores in the study area.

Exactly, there is a national regulation, Regulation of the President No 112 of 2007 which

\begin{tabular}{|c|c|c|c|}
\hline \multirow{2}{*}{ Districts } & \multirow{2}{*}{ Modern Stores } & \multicolumn{2}{|c|}{ Distance Modern Stores to Traditional Market } \\
\hline & & Distance $>500 \mathrm{~m}$ & Distance $<500 \mathrm{~m}$ \\
\hline Sukolilo & 3 & 2 & 1 \\
\hline Kayen & 2 & 1 & 1 \\
\hline Tambakromo & 1 & 1 & \\
\hline Winong & 1 & & 1 \\
\hline Batangan & 3 & & 3 \\
\hline Juwana & 6 & 4 & 2 \\
\hline Pati & 20 & 17 & 3 \\
\hline Gabus & 2 & & 2 \\
\hline Margorejo & 1 & 1 & \\
\hline Gembong & 1 & & 1 \\
\hline Tlogowungu & 1 & & 1 \\
\hline Wedarijaksa & 2 & & 2 \\
\hline Margoyoso & 5 & 4 & 1 \\
\hline Tayu & 5 & 4 & 1 \\
\hline Total Modern Stores & 53 & 34 & 19 \\
\hline Proportion (\%) & 100 & 64.15 & 35.84 \\
\hline
\end{tabular}

Source: Survey, 2015 
Table 3.

Most Vulnerable Traditional Markets Having Negative Impacts of Modern Stores

\begin{tabular}{|c|c|c|}
\hline District & Modern Stores to Markets (m) & Name of Markets Vulnerable Impacts \\
\hline Sukolilo & 24 & Sukolilo Market \\
\hline Kayen & 50 & Kayen Market \\
\hline Winong & 50 & Winong Market \\
\hline Batangan & 30 & Batursari Market \\
\hline Batangan & 30 & Batursari Market \\
\hline Batangan & 20 & Kuniran Market \\
\hline Juwana & 100 & Gowong Lor Market \\
\hline Juwana & 400 & Kudukeras Market \\
\hline Pati & 300 & Patikidul Market \\
\hline Pati & 400 & Ngarus Market \\
\hline Pati & 200 & Rogowongso Market \\
\hline Gabus & 50 & Karaban Market \\
\hline Gabus & 300 & Gabus Market \\
\hline Gembong & 50 & Gembong Market \\
\hline Tlogowungu & 200 & Tlogorejo Market \\
\hline Wedarijaksa & 300 & Wedarijaksa Market \\
\hline Wedarijaksa & 150 & Wedarijaksa Market \\
\hline Margoyoso & 300 & Bulumanis Market \\
\hline Tayu & 400 & Tayu Market \\
\hline
\end{tabular}

Source: Survey, 2015

implies to regulate the distance between modern stores to the existing traditional markets. The regulation states that establishment of shopping centers and modern stores must: (a) extrapolate the social-economic condition of the community, the presence of traditional markets, small enterprises and medium enterprises existing in the area concerned; (b) observe the distance to pre-existing traditional markets; and (c) provide parking space for at least 1 (one) four-wheel motor vehicle per 60 $\mathrm{m} 2$ (sixty meters square) of retail space of shopping centers and/or modern stores. Dealing with the regulation, it is mandated for local government to manage the establishment of modern stores.

There are 19 of 53 modern stores (35.84\%) which are established too near to traditional markets. The previous study conducted by Pusoro (2007) stated that the existence of supermarket influenced the decreasing performance of traditional markets. Dealing with it, the traditional markets having distances less than 500 meters to modern stores are vulnerable to decrease their performance. The traditional markets which are vulnerable to have negative impacts or to decrease their performance are shown in the Table 3.
In managing modern stores, especially responding to the distance of traditional markets, there are some lessons from other local government. Firstly, lessons learned from Surakarta, the local government has a local regulation (Perda) on managing shopping centers and modern stores. It is the local government regulation No 5 of 2011 on shopping centers and modern stores. The regulation states that establishment of shopping centers and modern stores are forbidden in the sites which have a distance less than 500 meters from traditional markets.

Secondly, lessons learned from Sukoharjo Regency, the local government regulation No 3 of 2011 on Managing Traditional Markets, Shopping centers, and Modern stores. The regulation states that the distance between shopping centers and modern stores to traditional Markets is at least 1000 meters (1 kilometer).

Thirdly, lessons learned from Jakarta (DKI), The Regulation of Local Government No 2 of 2002 and Regulation of Governor No 44 of 2003 regulate private markets in Jakarta. The regulation governs the distance among modern stores and traditional markets. The regulation states that establishment 
of (a) private markets having $100 \mathrm{~m}^{2}$ to $200 \mathrm{~m}^{2}$ of retail space must be having distance at least 500 meters (0.5 kilometer) from traditional markets; (b) private markets having $200 \mathrm{~m}^{2}$ to $1,000 \mathrm{~m}^{2}$ of retail space must be having distance at least 1,000 meters (1 kilometer) from traditional markets; (c) private markets having $1,000 \mathrm{~m}^{2}$ to $2,000 \mathrm{~m}^{2}$ of retail space must be having distance at least 2,000 meters (2 kilometers) from traditional markets; (d) private markets having 2,000 $\mathrm{m}^{2}$ to $4,000 \mathrm{~m}^{2}$ of retail space must be having distance at least 2000 meters (2 kilometers) from traditional markets; (e) private markets having more than $4,000 \mathrm{~m}^{2}$ of retail space must be having distance at least 2,500 meters (2.5 kilometer) from traditional markets. Those are some lessons learned from three local governments which may be taken for adoption in regulation policy dealing with the distance between modern stores being established from pre-existing traditional markets.

\section{The Advantages and Disadvantages of Modern Stores for Community Development}

Modern stores may have advantages and disadvantages for community development. There are some disadvantages of modern stores. Firstly, the modern stores may influence the performance of traditional markets when they are established near them. The traditional market "Rogowongso" for instance, get less and less customers after the establishment of supermarket "Luwes" which is located about 200 meters from it. Therefore, traditional retailers will be vulnerable to decrease their income and profit. Secondly, modern stores may cause a congestion when they do not provide a parking area properly. The supermarket "Luwes" provide a parking area less than standard especially the parking area for cars, so many cars of the customers use public area (side of the road) as a parking area. The impact is that a congestion often takes place in front of the supermarket. Responding to the case, the role of the local government is to manage modern stores, including distribution and implementation of regulation, not to stop the serving permits of them.

On the other hand, modern stores also have potential advantages to support community development. The term "community" is diverse groups of people who live in a commonly understood location or place. The place may be a neighborhood, a town/city, or a county and community development is a process that helps a community to sustain itself socially, economically, and environmentally.

There are some advantages dealing with the existence of modern stores. Firstly, the establishment of modern stores is able to enlarge employment so the modern stores are useful to reduce unemployment. The International Labor Organization (ILO) defines unemployment as numbers of the economically active population who are without work but available for and seeking for work, including people who have lost their jobs and those who have voluntarily left work (Hassan, 2013). Since the outbreak of the crisis, employment growth has slowed to $1.2 \%$ per annum between 2007 and 2014. On current trends, unemployment will continue to rise as the labor force expands. Going forward, job creation is expected to remain at this lower growth rate over the medium term, causing a widening of the global jobs gap to around 82 million jobs in 2019. If new labor market entrance is taken into account, 280 million jobs will need to be created over the coming five years to close the crisis-related global jobs gap and to absorb the increase in the labor force (ILO, 2015). The strategy to reduce unemployment can be different among local governments. However, the opportunity of employment should be managed properly, including the establishment of modern stores. They are useful to improve the opportunity of employment so the modern stores are useful to reduce unemployment.

The establishment of modern stores in Pati Regency has a role in enlarging employment. There are 51 minimarkets and 2 supermarkets in the study area. Employees for a minimarket are 8-12 persons. If the average employees are 10 persons for a minimarket so they provide 510 employments. Then the supermarket "Luwes" has 266 employees and the supermarket "Ada" has 240 employees. Therefore, the total employees of the modern stores in the study area are 1,016 persons. It means that modern stores have a role in enlarging employment.

Secondly, the existence of modern stores employ workers or labor-force which has the potential to increase community income. Most employees of the modern stores usually buy food and drink for their lunch and dinner in their surrounding workplace. It means that food sellers in the areas have potentials to increase their income. The price of the food and drink for lunch or dinner in the study area is $6,000-10,000$ IDR for once. If every employee buys foods and drinks only once a day and the average price is 8,000 IDR, so the potential income for the community (canteen owners) is 8,128,000 IDR a day derived from 8,000 IDR x 1,016 employees, $243,840,000$ IDR a month and 2,926,080,000 IDR a year. There is a relation between employment and the increase of community incomes.

Recently, vulnerable employment is falling slightly and it may cause vulnerable economic development for the community. ILO (2015) stated that vulnerable employment is the share of ownaccount work and contributing family employment. South Asia and Sub-Saharan Africa account for most of the vulnerable employment globally - for both, 
Table 4.

The Roles of Modern Stores in Community Development

\begin{tabular}{|c|c|c|c|c|c|}
\hline Districts & Modern Stores & Name & Location (Village) & Partnership & Status of UMKM \\
\hline Batangan & 1 of 3 & Indomaret & Batursari & Yes & Rental \\
\hline \multirow[t]{5}{*}{ Juwana } & 5 of 6 & Indomaret & Gowong Kidul & Yes & Rental \\
\hline & & Indomaret & Gowong Lor & Yes & Rental \\
\hline & & Indomaret & Kauman & Yes & Rental \\
\hline & & Alfamart & Kauman & Yes & Rental \\
\hline & & Alfamart & Kudukeras & Yes & Rental \\
\hline \multirow[t]{9}{*}{ Pati } & 10 of 18 & Alfamart & Patikidul & Yes & Rental \\
\hline & & Surya Baru & Patikidul & Yes & Rental \\
\hline & & Luwes & Patikidul & Yes & Rental \\
\hline & & Indomaret & Puri & Yes & Rental \\
\hline & & Alfamart & Puri & Yes & Rental \\
\hline & & Indomaret & Winong & Yes & Rental \\
\hline & & Alfamart & Patilor & Yes & Rental \\
\hline & & Indomaret & Parenggan & Yes & Rental \\
\hline & & Indomaret & Sidokerto & Yes & Rental \\
\hline Gabus & 1 of 2 & Indomaret & Karaban & Yes & Rental \\
\hline Gembong & 1 of 1 & Indomaret & Gembong & Yes & Rental \\
\hline Tlogowungu & 1 of 1 & Indomaret & Tlogorejo & Yes & Rental \\
\hline Wedarijaksa & 1 of 2 & Indomaret & Wedarijaksa & Yes & Rental \\
\hline Tayu & 1 of 4 & Indomaret & Tayuwetan & Yes & Rental \\
\hline Total & 20 of 50 & $20(40 \%)$ & & & \\
\hline
\end{tabular}

Source: Survey, 2015

it stood at over 75\% in 2013 (projected to decline only slightly by 2019). East Asia is the region that is likely to continue to make the most progress in reducing vulnerable employment, from 49.5\% in 2007 to $38.1 \%$ in 2019. Because there is a relation between employment and the increase of community incomes, the role of local government is to make a good policy for enlarging employments and increasing community incomes. Responding to the condition, the opportunity of modern stores employing workers or labor force in order to increase community income should be incorporated as long as they do not influence the performance of retailers in traditional markets.

Thirdly, the existence of modern stores will stimulate physical development in the surrounding area and has the potential to increase mutual partnership between modern stores and local community. The existence of modern stores can stimulate a drainage system in the area. Most buildings of minimarkets are rented from local community. The rental price is about 150 million IDR for ten years. Responding to the opportunity, some people who have houses in bad condition then they co-work with managers of minimarkets to build the houses as the cost of the rental price. It means that the existence of modern stores can stimulate physical development.

In addition, the existence of modern stores can stimulate the partnership with local small entrepreneurs. A part of modern stores in the study area has partnership with the local small entrepreneurs, especially informal traders (PKL). There are 20 modern stores which provide retail space for informal traders. It means that a part of modern stores has roles in community development in the study area. The modern stores which have the roles of community development by providing retail space for informal traders are shown in the Table 4.

The partnership between modern stores and the small traders can be the initial implementation of Regulation of the Trade Minister No. 68/M-Dag/ 
PER/10/2012 regarding the Franchise for Modern Store. This regulation governs the limit of the company owned outlet maximally 150 outlets and if exceeding such maximal limitation, then it is mandatory to franchise its business. The Regulation limits the number of company-owned franchise outlets to 150 . If a franchisor already has 150 stores and plans to increase the number, then $40 \%$ of the additional outlets should be franchised. For example, if a franchise owner with 150 outlets plans an additional 200 , then $40 \%$ of the 200 must be franchised.

Modern stores may have advantages and disadvantages for community development. In this case, the role of the local government is to manage the distribution of modern stores, not to stop the serving permits of them. Managing distribution of modern stores will reduce the negative impacts. On the other hand, remaining to serve permit of modern stores is useful to enlarge employment and to eliminate illegal mini markets.

\section{The Role of Local Public Policy in Managing Modern Stores}

Modern stores in Pati Regency grows very rapidly but part of them are in problems. Some have no permit or misusage of the permits and the other modern stores are established near traditional markets. The problems become essential issues of community development. Responding to the problems, community insists to stakeholders making a policy dealing with establishments of modern stores properly.

The issues of modern store problems made many parties including civil society and People's Representative Council (DPRD) realizing the impacts to pre-existing traditional markets. Therefore, they insist local government, especially executives, to make a regulation on modern stores. Follow up the issues, the local government of Pati Regency made a regulation, Regent Regulation No 60 of 2012 concerning Modern stores. Unfortunately, the regulation is not formulated properly. There are some weaknesses in the regulation. Firstly, the regulation does not govern the distance between modern stores being established and the pre-existing traditional market. It means that the regulation cannot overcome the problems dealing with the very near distance among modern stores to the traditional markets.

Secondly, there is a contradiction among substance in the regulation. Article 3 (Paragraph 3) for instance, states that businessmen who want to establish minimarkets must have permits (IUTM). It means that opportunity to run minimarkets is possible to be conducted by businessmen. On the other hand, Article 8 (Paragraph 8) states that for balance keeping the growth of minimarkets and traditional markets in order to empower UMKM, proposal of IUTM for minimarket establishment cannot be served after the Regulation of Regent is issued. The two articles are in contradiction in the sense of public policy. One encourages running business in minimarkets. The other article conducts moratorium for serving IUTM of minimarket establishment. As result, there are coming up minimarkets without permits. Some of the mini markets without permits exist in some districts which spread out in the eastern part of Pati Regency and in the southern part of the regency.

The fundamentally mistaken substances of the Regent Regulation No. 60/2012 on Modern stores in Pati Regency is that the policy for stopping minimarket establishment has no legally constitutional reference. There is no national constitution in Indonesia which regulates for stopping minimarket establishment. The local regulation is likely improperly formulated. It is caused by a political manner at the time. The policy has been formulated in a short time and does not have a process properly. A Regent Regulation is included in public policies.

Normatively, a public policy is formulated by using certain steps. Anderson in Subarsono (2005) stated that public policy consists of the following steps: (1) agenda setting, selecting public issues which is necessary to overcome; (2) policy formulation, identifying policies which are possibly used to handle the issues; (3) policy adoption, selecting choices of the policy by supporting administrator and legislative. The policy adoption is conducted after the process of recommendation is over; (4) policy implementation, it is the phase in which the follow-up of policy adoption is conducted by related institutions with supporting available resources; and (5) policy assessment, it is the phase in which evaluation is conducted to determine the existing of effectiveness and efficiency of the policy.

A public policy always has different contents but mainly there are some similarities. Firstly, a purpose statement, outlining why the organization is issuing the policy, and what its desired effect or outcome of the policy should be. Secondly, an applicability and scope statement, describing who the policy affects and which actions are impacted by the policy. The applicability and scope may expressly exclude certain people, organizations, or actions from the policy requirements. Applicability and scope are used to focus the policy on only the desired targets, and avoid unintended consequences where possible. Thirdly, an effective date which indicates when the policy comes into force. Retroactive policies are rare, but can be found. Fourthly, a responsibilities section, indicating which parties and organizations are responsible for carrying out individual policy statements. Many policies may require the 
establishment of some ongoing function or action. For example, a purchasing policy might specify that a purchasing office is created to process purchase requests and that this office would be responsible for ongoing actions. Responsibilities often include identification of any relevant oversight and/or governance structures. Fifthly, policy statements indicating the specific regulations, requirements, or modifications to organizational behavior that the policy is creating.

Shortly, there are some weaknesses of the Regent Regulation No 60 of 2012 on Modern stores in Pati Regency. One, the regulation does not govern the distance between modern stores being established and the pre-existing traditional market. Two, there is a contradiction among substance in the regulation. Three, the fundamentally mistaken substance is that the policy for stopping minimarket establishment has no legal constitutional reference. Therefore, the review of the Regent Regulation No 60 of 2012 on Modern stores in Pati Regency should be conducted to eliminate the weaknesses. Hopefully, modern stores grow smoothly to support the community in the term of providing more employment and reducing unemployment, also increasing community income, especially for workers. However, the modern stores should be managed properly in order not to influence the performance of traditional markets.

\section{Conclusion}

There are five findings in the study. Firstly, modern stores including mini market and supermarket in the study area have grown rapidly in average 5 new modern stores annually. Secondly, the local government is relatively weak to control the modern stores in which 9 of 53 modern stores are in problems with their permits. Thirdly, the distribution of modern stores is also not well managed, in fact, 19 of 53 modern stores (35.84\%) are established in the sites near the existing traditional markets. Fourthly, the Regent Regulation Number 60 in 2012 in Pati Regency has some weaknesses including: (a) the regulation does not govern the distance between modern store being established and the pre-existing traditional market; (b) contradiction among substances in the regulation, especially concerning moratorium of permit serving for establishment of minimarket which has no constitutional reference. Fifthly, modern stores have roles in enlarging employment and even 20 modern stores have roles in community development by providing retail space for informal traders.

Responding to the existence of modern stores in the study area, it is better for local government to do the following policies. Firstly, to sustain traditional markets, local government should manage the distribution of modern stores by using requirements of modern store establishment having distance at least 500 meters to traditional markets. Secondly, the modern stores which have permits but the distance are less than 500 meters to traditional markets, they should be demanded to conduct partnership with UMKM as CSR (corporate social responsibility) in term of selling local products. Thirdly, the modern stores which have no permits or do not obey the permits should be demanded to obey the regulations. All modern stores should be controlled for operating suitable to the regulation including for providing feasible parking areas. Fourthly, the Regulation of Regent No 60/2012 on Modern stores in Pati Regency has some weaknesses so it should be reviewed including (a) distance among modern stores and traditional markets at least 500 metres; (b) the modern stores having national scale, and wanting to establish new of stores should be required to obey the Regulation of the Trade Minister No 68/M-Dag/ PER/10/2012 regarding the Franchise for Modern Store, namely $40 \%$ of retail space be franchised for UMKM in local areas. Fifthly, new modern store establishment should be directed to the area (sub-district) which has no traditional market to stimulate the distribution of food accessibility for the community. Modern stores are still needed for community development so modern store should be managed well suitable to the local context. Serving for the establishment of modern stores should be maintained as long as the distance between modern stores and pre-existing traditional markets is reasonable, not too near.

\section{ACKNOWLEDGEMENT}

I (writer) appreciate to the related parties who support to carry out the research. Firstly, the chief of research and development office and staff who provide resources to conduct the research. Secondly, the chief of integrated service office (Kayandu) and staff who support in providing data of modern store permits. Thirdly, the chief of industry and trading agency (Disperindag) and staff who support to provide data of local government traditional markets. Fourthly, the chief of the board of empowerment for villages (Bappermades) and staff who support to provide data of village traditional markets. Fifthly, society and other parties are as person resources or informants who help in conducting this research.

\section{REFERENCES}

Aryani, D. (2016). Efek Pendapatan Pedagang Tradisional dari Ramainya Kemunculan Minimarket di Kota Malang. Jurnal Dinamika Manajemen, 2(2), 169-180. Retrieved from http://journal.unnes.ac.id/artikel_nju/ 
$\mathrm{jdm} / 2481$

Fadhilah, A. (2011). Dampak Minimarket terhadap Pasar Tradisional (Studi Kasus di Ngaliyan) (Undergraduate Thesis). Institut Agama Islam Negeri Walisongo.

Hassan, \& Makinde, O. (2013). Curbing the Unemployment Problem in Nigeria Through Entrepreneurial Development. African Journal Of Business Management, 7(44), 4429-4444. Retrieved from http://www.academicjournals. org/article/article1390925779_Hassan.pdf

Iffah, M., Sutikno, F., \& Sari, N. (2016). Pengaruh Toko Modern terhadap Toko Usaha Kecil Skala Lingkungan (Studi Kasus: Minimarket Kecamatan Blimbing, Kota Malang). Jurnal Tata Kota Dan Daerah, 3(1), 55-64. Retrieved from http://tatakota.ub.ac.id/index.php/tatakota/ article/view/129

Majee, W. \& Hoyt, A. (2011). Cooperatives and Community Development: A Perspective on the Use of Cooperatives in Development. Journal Of Community Practice, 19(1), 48-61. http:// dx.doi.org/10.1080/10705422.2011.550260

Nugroho, R. (2006). Kebijakan Publik di Negaranegara Berkembang. Jakarta: Gramedia.
Poesoro, A. (2007, April/May). Traditional Markets in the Era of Global Competition. SMERU, 22, 3-10.

Sihotang, R., Sembiring, S., \& Rahmanta,. (2014). Pengaruh Pasar Moderen terhadap Pedagang Pasar Tradisional dan Masyarakat dalam Pengembangan Wilayah di Kecamatan Medan Area. Jurnal Ekonom, 17(4), 181-194. Retrieved from http://repository.usu.ac.id/ handle/123456789/43581

Subarsono, A. (2005). Analisis Kebijakan Publik: Konsep, Teori, dan Aplikasi. Yogyakarta: Pustaka Pelajar.

Vargas - Hernández, J., Noruzi, M., \& Irani, F. (2011). What is Policy, Social Policy and Social Policy Changing? International Journal of Business And Social Science, 2(10), 287-291.

Widiandra, D. \& Sasana, H. (2013). Analisis Dampak Keberadaan Pasar Modern terhadap Keuntungan Usaha Pedagang Pasar Tradisional (Studi Kasus di Pasar Tradisional Kecamatan Banyumanik Kota Semarang). Diponegoro Journal Of Economics, 2(1), 1-6. Retrieved from http://ejournal-s1.undip.ac.id/index.php/ jme/article/view/1959 